DOI 10.20396/temáticas.v20i40.11430

\title{
COMO SER BRASILERA LÁ E EUROPÉIA AQUI
}

\author{
Maria Cecília Patrício*
}

RESUMO: O objetivo principal deste artigo é destacar, através das trajetórias de viagem e das representações de travestis brasileiras, as formas pelas quais elas se intitulam e se legitimam, com destaque na circulação entre países, identificando nelas uma brasilidade, assim como uma europeidade como marca de quem pode absorver características novas em sua configuração identitária. Identifico que as trajetórias estão vinculadas a noções como habitus de travestilidade, enquanto fenômeno que as acompanha desde quando iniciam suas modificações corporais e vivências com outras travestis no Brasil. Nos dois lugares, Recife e Madri, aparecem imagens de Brasil que ora concordam com os modelos já estabelecidos historicamente, ora discordam do que é vendido pelas mesmas quando estão de volta ao seu país, onde surgem novos comportamentos trazidos de um novo mundo descoberto por elas e vislumbrado por tantas que ainda não conseguiram acessar: a Europa. Assim, as vantagens e desvantagens em ser brasileira na Espanha aparecem principalmente quando se percebe que a violência vivenciada no Brasil é um dos fatores de estímulo para elas estarem circulando entre países, pois, evitam-se situações de risco.

PALAVRAS-CHAVE: travestis brasileiras, Brasil e Espanha, identidade nacional.

\footnotetext{
* Doutora em Antropologia Social pela Universidade Federal de Pernambuco. E-mail: mcecpatricio@uol.com.br.
} 


\subsection{CONTEXTUALIZANDO O CAMPO, RECIFE}

Neste ponto do artigo discutirei como o Recife ${ }^{1}$ se coloca como cidade metropolitana, capital de Pernambuco, lugar onde transitam pessoas, eventos e produtos ${ }^{2}$ do mundo todo, desde os primórdios de sua história. Analiso-o como microcosmo social que contribui para o estabelecimento do habitus, enquanto categoria que estabelece disposições duráveis e comportamentos, de travestis, assim como rota de trânsito entre Brasil e Europa.

Recife é cidade turística e, por isso, com estrutura que contribui para manter uma rede de agências de hotéis, restaurantes e pequenos negócios do entretenimento (Pinheiro, 2005) funcionando o ano inteiro. É a mesma cidade que desenvolveu a prostituição de porto, em que mulheres e travestis que ali moravam e trabalhavam satisfaziam principalmente à população de homens que vinham de alto mar para desembarcar mercadorias e desaguar energias, a mesma cidade que, dentre tão vasta diversidade, ainda preserva um modelo de família patriarcal (Del Priori, 2000), tal como já relatara Gilberto Freyre (1999), em conjunto com aspectos de comportamentos que desviam da norma pré-estabelecida. Comportamentos estes rechaçados por uma parcela da população mantenedora de uma moral heteronormativa, diga-se de passagem, machista e preconceituosa. Porém, mantidos por uma outra parcela consumidora dos mitiès e zonas de diversão alternativas, sejam clientes, empresários ou intermédiários, como taxistas, agenciadores e curiosos.

O Recife, que faz nascer suas filhas travestis, sejam da cidade ou do interior do estado, que buscam madrinhas nas casas de cafetinas e mães

\footnotetext{
${ }^{1}$ A origem do nome vem de sua formação geográfica: região de arrecifes. Como cidade, iniciou-se a partir da Freguesia de São Frei Pedro Gonçalves (Morais, 2007), o que conhecemos hoje como bairro do Recife Antigo, área portuária, à beira do Atlântico e entre rios. Ali se destacavam tabernas e prostíbulos, alimentados pelos visitantes e pela população que o rodeava, o que influenciou na moda e nos modos das pessoas, que passavam a consumir o que vendiam, os mascates, e a participar das variadas manifestações públicas que por aqueles idos aconteciam. ${ }^{2} \mathrm{Na}$ lista de produtos que circulam pelo Recife, via porto, aeroporto e rodoviárias, tem de tudo, principalmente drogas.
} 
protetoras e educadoras de uma realidade de aprendizado de vida nova, como bem retrata Denise e Ellen:

\begin{abstract}
Aí fiquei morando na Rio Branco, aí um dia eu disse assim a mulher (...): "Eu posso ficar morando aí na sua pensão? Aí a mulher disse: Olhe, você só pode ficar morando aqui na minha pensão se você ficar fazendo programa... [Porque] eu caí na época do baixo meretrício. Eu lembro que a gente não vivia, a gente vegetava, que a gente descia, muito bonita, e naquela época tinha muito militar, muito recruta do exército que ia pra zona atrás de prostituição, marinha, naquele tempo eram muitas mulheres, muita prostituição. Então eles se juntavam de dez pra pegar o travesti e dar uma pisa. E eu, quando eu cheguei logo, a primeira vez que eu entrei na zona da Rio Branco, entrou eu, a finada Flor, finada Selma, finada Groselha e a finada Tecia ... tudo meninos novos, comigo era seis. (Denise)

(...) cafetinagem é uma questão de educação da travesti. O travesti de 12,13 anos já é cafetinado pelas pessoas que acolhem porque tu tem um filho travesti, não quer ele, ele vai, fica na rua, ele vai dormir onde? Aí um chega e fala "Tu dorme na minha casa. Tu me paga tanto". Aí já começa a educação, cafetinagem - travesti. (Ellen)
\end{abstract}

Estas falas mostram duas situações diferentes dentro de uma mesma realidade. Uma é a violência que sofre a travesti jovem por ter sido expulsa da casa de familiares e por isso precisou da casa da cafetina como apoio, mas nessa situação lidou com a violência urbana, o que a cafetina não pode evitar. Neste sentido, os termos êmicos "car̂" e "descr̂" podem ser entendidos como representando categorias marcadas por um caráter moral que está implícito no universo do mercado do sexo de trottoir, uma moral implícita no movimento do corpo das meninas que saem para a rua, "para baixo", degenerando na escala social, tal como fica implícito para Denise, que hoje critica a formação que teve utilizando o termo "vegetava", significando degradação, embora com a possibilidade de sobreviver no trabalho pela 
quantidade de oferta de clientes que aportavam naquele espaço em busca de prazer sexual, no qual o corpo está em evidência seja como objeto de desejo enquanto corpo feminino, mas também como "saco de pancada" pela sua ambiguidade.

A fala de Ellen informa o lado educativo que a cafetinagem tem para a travestilidade, o da aprendizagem e com isso as trocas de favores e acesso a outros espaços de trabalho, o que inclui a Europa, experiência vivida por ela. Ambas as colocações indicam a cafetinagem como laço de proteção, seja em termos de ter um espaço para dormir, uma oportunidade de ganhar dinheiro e se inserir no mercado de trabalho - do sexo - e aprendizagem, assim como, algumas vezes, de ter apoio no trottoir, o que as duas trans não incluíram em suas falas.

O Recife da diversidade enquanto um indicativo de vida metropolitana, se fez ouvir através de manifestações políticas históricas, muitas delas com caráter de gênero. Tem na sua história uma referência de reforma urbana e de cotidiano baseado em modelos europeus - a reforma de Hausmann, no que concerne a arquitetura e urbanismo -, unida também à reforma no comportamento das pessoas, reformas sanitárias nos mesmos moldes instalados na capital do país, que até meados do século XX era o Rio de Janeiro. O Recife que, como o Brasil, se esmera e ainda tem no centro primeiromundista um modelo. Por isso, destino de muitas travestis para aquele continente.

Minha filha, eu amo essa cidade de uma maneira assim... porque assim, porque a Boa Vista ${ }^{3}$ é uma Broadway, é o centro de Roma, ela é o centro dos Estados Unidos. Ela tem o Empire States. Ela tem pontes, ela tem Torre Eiffel, ela tem tudo, um pouquinho de cada coisa. Ela tem assalto, ela tem morte, ela tem prostituição, ela tem tráfico, ela tem vida, ela tem evangelização, ela tem igreja, ela tem casa de

\footnotetext{
${ }^{3}$ Conde da Boa Vista é uma das principais ruas do bairro que leva o mesmo nome, Boa Vista, bairro central do Recife.
}

Temáticas, Campinas, 20(40): PG-PG, ago./dez. 2012 
prostituição, e isso é coligado. A Conde da Boa Vista é coligado a Recife então ela é um coração. E pra saber que você está viva, você tem que saber se o coração bate. A Boa Vista bate 24 horas dentro de Recife. É isso que é. (Ellen)

O Recife dos babitus de Ellen que, em sua fala, percebe a importância de visualizar aqui aspectos de um mundo globalizado e comparado com o que há de "melhor" no mundo, uma metropolização que permite a convivência de imagens.

Cidade que se abre para o cenário internacional, onde desembarcam trabalhadores, estudantes e turistas, que vêm buscar negócios e entretenimento, assim como o sexo. Enquanto rota, é o que Parker afirma como "parte de um sistema interativo maior que liga diferentes comunidades em locais distintos através do fluxo contínuo de capital, pessoas e idéias" (Parker, 2002, p. 237). Por isso, se firma como espaço em que o turismo, principalmente o sexual, atrai nas travestis daqui o olhar para o outro, a Europa e o europeu.

\subsection{IMAGENS DE BRASIL E DE BRASILEIRO FORA DE CASA}

Para Silva, a travesti aparece como a transformação do malandro. "Não que o malandro tenha se transformado em travesti, mas é a sua roupagem, do homem da noite que modificou, do boêmio, do malandro ao travesti" (Silva, 1993: p. 3). Mas, também quando compara a travesti à "mulher de malandro": aquela que pena pelo seu homem, que sofre por causa de seu parceiro boêmio, principalmente por ser a outra.

A imagem da mulher é a da mulata. Estereotipada e copiada em todo o mundo, a figura da mulata está presente na Espanha, assim como a do malandro como o homem brasileiro, de forma alegórica e folclórica. Figuras estas que aparecem nas festas de rua, atuando em casas de festas, boates, escortes (festas particulares) e grandes eventos do turismo internacional.

Ser mulata não se resume à cor da pele, mas indica uma suposta performance em jeitinho de sambar, em malemolência e sensualidade, 
demonstrados através da roupa que é usada na maior parte de nosso ano quente, e de um corpo educado pela sedução do andar leve e sinuoso que "só a brasileira tem" (Ellen), e que elas gostam tanto de reforçar.

Aparece também a relação entre ser brasileira e garota de programa. E um bom exemplo é o de Camila, travesti de Campina Grande, já há algum tempo circulando pela Espanha, de pele branca, que na Sala de Festa alterna como prostituta:

C: Na Espanha, a gente não é contratada como prostituta pra alternar ${ }^{4}$ não, a gente é contratada como artista. Nós somos os espetáculos da casa. Todo mundo sabe que a 1:00h elas fazem um show e às 4:00h fazem outro show, entendeu? Só que na sala tem muitos clientes que gostam de travestis e com isso nós estamos lá pra sacar copas, copas é o que? Copa é bebida que o cliente oferece a você. O cliente paga a você pra você beber e estar com ele. (...) Lá é assim: Ficam todas sentadas no sofá. Quando chega um cliente, de uma em uma vai atender, (...) pergunta o que ele quer beber e se ele quer invitar [convidar para] alguna copa, se ele gosta ele invita, se não gosta, fica na dele, se ele encontrar alguma que ele quer, ele manda chamar... Existe a parte da boate, (...) do dancing, (...) do reservado, (...) da barra que é onde fica o camareiro que vem os homens e pede bebida. (...) Se ele invita uma copa de cinco mil [pesetas] ${ }^{5}$ ele tem o direito de se sentar na Sala com você que é um lugar mais escuro, mais aconchegante e se invita de 10 mil ele tem o direito a entrar no reservado com vocế. (Camila)

\footnotetext{
${ }^{4}$ Significa ter alternância, revezar, variar sucessivamente. No caso do estudo na Espanha significa, ao mesmo tempo, trabalhar em clubes de Alterne recebendo clientes da casa alternando com outras garotas. No sentido em que várias são contratadas para realizar programas de forma em que o estabelecimento possa oferecer uma diversidade de modelos em períodos também alternados.

${ }^{5}$ Moeda vigente na Espanha no momento em que Camila esteve pela última vez neste país, antes de me conceder entrevista.

${ }^{6}$ Entrevista concedida em 2001.
} 
Camila tenta diminuir o estigma da atividade que vai assumir na Espanha. Realiza este trabalho apenas como alternância ${ }^{7}$, pelo fato de ser artista e ali satisfazer clientes que estão carentes de companhia na noite, o que caracteriza a representação de sermos "as melhores damas de companhia do mundo", sem por isso merecer o jargão de prostituta. Segundo Piscitelli (2005), não somos as mais bem pagas, logo assim, melhores, principalmente quando se trata das garotas do leste europeu que conseguem ganhar mais euros em menos tempo que qualquer outra estrangeira que ali realize a mesma atividade? Embora, em outro momento, segundo uma comparação específica, a mesma autora afirme que na região da Galícia,

"de acordo com estudos realizados em espaços fechados, clientes casados e solteiros que procuram sexo e companhia preferem abertamente trabalhadoras do sexo brasileiras, tidas como jovens, alegres e com melhor disposição para o sexo (uma "relação natural e sem inibições") do que as portuguesas"

Nas falas das travestis se constata a discriminação no mercado de trabalho. No Recife, a maioria se dedica ao mercado do sexo. Algumas poucas realizam outras atividades, como é o caso da enfermeira Eline, e da miss Aleika. Sobra o mundo do espetáculo para algumas que circulam pelo universo das poucas casas de shows que contratam seus serviços. Sobre isso, Cris Falcão reflete:

\footnotetext{
${ }^{7}$ Não é à toa que o local que lhe contratou na realidade se chama Club de Alterne, o mesmo que Salas de Festa, como afirma Camila. Ou seja, locais de diversão noturna onde garotas fazem shows musicais e de dança como atrações para os clientes, que tem também opções de terem como companhia alguma garota, ou travesti, em ambientes mais reservados do clube.

${ }^{8}$ Compreendo, através das falas, "sermos melhores" como uma vantagem em relação à afetividade que as brasileiras apontam oferecer aos clientes quando em atividade sexual, o que muitas profissionais do sexo de outras nacionalidades não apontam em seu discurso. Mais uma vez ver Piscitelli (2005).

${ }^{9}$ O que está montado por um esquema de organização do tempo no ato sexual.
} 
Viado no Brasil só nasceu pra ser cabeleireiro, costureiro, né? Estilista ou trabalhar numa cozinha, né? Ou ser empregada doméstica ou prostituta. São raras as pessoas que você vê, como eu, que tenta fazer alguma coisa. Que já foi proprietário de uma casa noturna, que tem um salão ou que procure fazer uma vida normal aqui dentro do país. (Cris Falcão)

Dar emprego para travesti é coisa difícil. É por isso mesmo que Cris aponta as dificuldades, ela mesma se inserindo neste mercado de trabalho que acabou de denunciar como restrito. Empresas públicas ou privadas dos dois países analisados resistem a colocar em seus quadros pessoas que demonstrem certa androginia ou ambigüidade (Silva, 1993; 1996) em seu gênero.

O Brasil é representado pelas travestis como um país preconceituoso, pois, por exemplo, o nome de registro na forma de tratamento de uma travesti, assim como a referência ao sexo masculino na sua condição de gênero, são mais fortes do que a aparência e o comportamento feminino daquela pessoa. Roberta Close, na década de 1980, por exemplo, já passou por isso em aeroportos, ao tentar comprovar que o Luiz do passaporte é a mesma pessoa que a foto mostra. Assim como ocorreu com Cris Falcão. Desta forma, pois, desvincular a identidade de gênero da identidade civil, fixa, imutável, no papel, é algo ritualístico (Campos, 1999) na identificação civil, o que ocorre nas alfândegas e também em outros espaços, como afirma a entrevistada:

Você vai numa loja, aqui mesmo, se eu for numa loja, eles estão me chamando de ela, ela, ela, ela, aí eu vou, dou meu cartão de crédito, no meu cartão de crédito tem meu nome masculino, a partir daquele momento que eles olham, muitas vezes já perguntaram assim: "Quem é esse aqui?” Aí eu: "Por favor. Fala baixo. Sou eu”. Aí, ela Ah! Não sei o quê! Não sei o quê! Ah! Dá pra ele assinar. Na mesma hora já muda totalmente... (Cris Falcão)

Unida à identidade masculina, gravada no documento civil, o que incomoda é o nome masculino, muitas vezes visto como impossível de 
pertencer à pessoa fotografada, o que gera constrangimento em relação ao nome da pessoa travesti. Questões próximas a esta foram estudadas por Silva (2008), que esclarece ser pior a presença do documento com nome e sexo masculinos do que os termos criados para denominar a pessoa, como "bonecas" na década de 70, e atualmente "travesti", para algumas que resistem a continuar utilizando este nome em referência à marginalidade das ruas direcionada à figura de muitas travestis.

Ellen me afirmou que ser brasileira é usar "roupas de brasileira" quente, com o que concordou Anjo, afirmando que as brasileiras são como pimenta. Sempre em comparação com a figura da européia:

A mulher européia anda sempre bem maquiada e sempre bem vestida, e bem tapada as partes sexuais. Não tem essa sensualidade da roupa colada da latina americana. E a brasileira é a brasileira quente, é aquela roupa assim... Eu andei assim em Lisboa [neste momento se posicionou na cadeira me apontando a forma como estava vestida] o mundo todo olhou pra mim e você se sente diferente (Ellen)

O sentir-se diferente de Ellen decorre da roupa e da sexualidade, o que denota uma brasilidade em relação a uma noção construída para e pelo consumo exterior, assim como reforça a sensualidade como característica que concorda com as imagens de Brasil em propagandas de agências de turismo. Brasileiras enquanto figuras femininas com pouca roupa, peles bronzeadas pelo sol quente que molda seu comportamento também quente durante todo o ano. Por isso, nas falas de muitas delas, o Brasil é um país moldado pela sua geografia, clima e histórias de índios e bons negócios, o que bem define LéviStrauss em seus Tristes, e cada dia mais quentes, Trópicos.

\footnotetext{
${ }^{10}$ Em situações de compras descobri que nossas calças jeans saint-tropez, de origem, pelo menos de nome, francesa, são pelos espanhóis chamadas de pantalones colombianos pois são moda na colômbia e fazem sucesso entre as mulheres de robusta estatura daquele país, embora a origem do produto não seja necessariamente da Colômbia, muitas delas são do Brasil, outras, como não poderiam deixar de ser, são fabricadas na China.
} 
Brasil: país do futebol, das praias e da mulata; quando sabem que você é brasileira, as pessoas logo associam uma coisa à outra e logo aparecem os "ronaldinhos" e os "sambinhas desengonçados". Muitas pessoas da Espanha desconhecem a região de onde partiu este estudo. A mídia veicula informações limitadas sobre o Brasil, em sua maioria questões políticas de interesse mundial ou casos que chocam o mundo. A internet é um veículo em que as pessoas buscam informações mais aprofundadas sobre nosso país, mesmo assim prevalecem os painéis de agências de turismo que permanecem com os mesmos roteiros e paisagens: praias, coqueiros, mulheres ${ }^{11}$, futebol, matas..., assim como a própria informação veiculada por um anúncio que uma das trans na Espanha mostra:

Geysa Mya ${ }^{12}$ : Site Eros Guia. Super femenina, cariñosa, dulce, amable para complacerte. Soy muy salvaje recién llegada de la selva de Brasil. Proporciones exactas: mido $190 \mathrm{~cm}$ por casi $30 \mathrm{~cm}$ de ricura, 100 de caderas, 70 de cintura y $150 \mathrm{de}$ pecho. Me encanta dominar a los mens como activa, también soy dócil como pasiva. También parejas como algo especial. ${ }^{13}$

Alguns dados nesta citação foram colocados em itálico para serem analisados aqui. O primeiro deles é a selvageria. Há nele uma imagem de que a brasileira da qual se trata é da selva, da mata, por isso selvagem, dando

\footnotetext{
${ }^{11}$ Atualmente, o turismo sexual no Brasil tem uma vertente de gênero inversa. São as mulheres da Europa que vêm em busca de novas experiências sensuais, afetivas e sexuais com os homens "nativos" do nosso país. Tal fato foi confirmado em enquete por telefone de um programa de rádio (Movida brasileña) que apresenta música e cultura brasileira todos os dias - Círculo de Bellas Artes, Madrid. Enquete esta realizada com algumas jovens espanholas sobre o que mais as atraía em nosso país: o resultado foi o imaginário de virilidade, exoticidade e satisfação sexual dos homens daqui.

${ }^{12} \mathrm{O}$ nome da anunciante foi modificado, para preservar sua identidade, embora saibamos que o nome de registro e de conhecimento desta travesti não é necessariamente o que ela expõe no anúncio.

${ }^{13}$ Utilizo esta informação em especial, mesmo não sendo exatamente de nenhuma das interlocutoras ouvidas no estudo, porque foi a mais adequada, devido à riqueza de informações e ao não comprometimento com as que expõem seus dados na internet na Espanha.
}

Temáticas, Campinas, 20(40): PG-PG, ago./dez. 2012 
conotação de pessoa de pouco cuidado especial em termos de cultura, de polidez erudita e intelectual, ao mesmo tempo de sexualidade forte como um felino, enquanto um animal não domesticado, o que denota algo de vigoroso em seu comportamento sexual, como também resistência, característica de alguns animais. $\mathrm{O}$ imaginário que aqui se percebe é o de um Brasil ainda colonial, próprio da imagem que se vendeu há bem pouco tempo atrás nas propagandas de mídia e agências de turismo sobre o país. Este imaginário se vincula a imagem de travesti como ser mitológico (Silva, 1993), o que chega a confundir nossa natureza com a natureza das pessoas.

Uma outra característica que aparece não apenas neste anúncio é a propaganda forte do tamanho do membro sexual das travestis como atributo de propaganda de si. No Recife, nos anúncios de jornal e internet, não havia até o ano de 2008 a menção ou exposição das características do membro viril masculino da travesti ${ }^{14}$, enquanto na Espanha é o maior frisson:

Lala

travestis brasileiras de 18 a 25 años, guapisimas y femeninas con preciosos cuerpos. con pechos grandes y pechos enormes. dotadas y super dotadas. muy potentes, activas y pasivas. piso climatizado, visa horario de 11 a $2 \mathrm{~h}$. Salidas y hotel. (www.travestispain.com)

\section{TRAVESTI}

mulata superlechera dotadisima. 64646464

\section{TRAVESTI}

jovencita. femenina, guapisima. superpechazos. ultradotacion. 9191919191

\section{TRAVESTI}

reina del sado, castigo con mi membro viril, 649646464. (periódico adn 18 de dezembro de 2006)

\footnotetext{
${ }^{14}$ A partir do primeiro semestre de 2008 , periódicos e agências na internet apontavam o membro viril das travestis como destaque. Sobre isso ver www.recifesex.com; e FIGUEIREDO, 2008.
} 
No Recife, algumas travestis mostram seus pênis a clientes, quando solicitadas, para demonstrar a possibilidade de prazer que eles poderão obter ao contratar os serviços daquela que está realizando trottoir. Na Espanha, a imagem marcante nos anúncios de que as travestis brasileiras têm membro sexual grande, indica uma origem mestiça que caracteriza esta população como mulata/o, termo que não na Espanha.

Mulato seria o "mestiço das raças branca e negra" do europeu e do africano quando se trata do/a brasileiro/a. Em uma concepção mais biologizante, origina-se da palavra mula, o produto do cruzamento do cavalo/égua com a asna/asno. Ou seja, um dos dois no cruzamento torna infértil a cria, o filhote, o que gera no novo ser apenas a utilidade para o trabalho e não para a reprodução, embora isso não exclua o fato de poderem praticar sexo.

Escolhi utilizar esta palavra, mulato, pelo fato das travestis, assim como os garotos de programa brasileiros, ou mesmo alguns da América Latina, utilizarem a origem e a mesticidade como diferencial de outros garotos e travestis que por lá trabalham e são de outras partes do mundo, com características distintas de atuação, como, por exemplo: "a primeira transex árabe na Espanha"16.

Abro um parênteses para falar um pouco sobre a relação de alteridade entre o Brasil e a Europa. Relação esta moldada através da imagem do turista que vem visitar nosso país. Conforme Urry (1999), "os turistas são brancos”, enquanto a figura do não-branco está no nativo, no negro, por exemplo. $\mathrm{O}$ autor se refere a esta exoticidade quando categoriza socialmente a figura do turista enquanto pessoa que pode viajar. Uma imagem de pele clara, estatura e poder aquisitivo alto, que atrai pelo fato de gerar uma leitura de que, na Europa, se pode ter acesso a, pelo menos, parte da riqueza do país. O que não é difícil, devido ao contato entre travestis brasileiras, como também mulheres, com o turismo sexual que muitos europeus vêm realizar aqui.

\footnotetext{
${ }^{15}$ Michaelis, 1998, p. 1423.

${ }^{16}$ Neste sentido, há o aspecto da exoticidade, pela novidade na propaganda de tal figura, o alerta para o imaginário acerca do erotismo no mundo árabe (principalmente na literatura), da sensualidade.
} 
Retornando aos anúncios sobre travestis brasileiras na Espanha e no Brasil, me reporto ao estudo de Messeder (2007), que analisou "homens pretos", brasileiros e angolanos. Estes, para a autora, se inserem no mito de virilidade quando se descobrem na situação de imigrantes, sozinhos e sem trabalho, na Galícia. Ao perceberem o mito, estampado nas relações cotidianas, se deparam com a indagação sobre a própria virilidade, e acabam percebendo o mercado do sexo, em expansão, como opção de trabalho.

Este mito está fundamentado na relação entre países africanos e europeus, tendo como pano de fundo a relação de alteridade, através de estereótipos marcados pela força humana, seja sexual ou de trabalho, que o homem imigrante, de cor mais escura desenvolve. Este mito também está fundamentado numa relação de raça e sexo que se desenvolve apenas quando o homem preto está na sociedade de acolhida, pois, o "mito da virilidade torna-se um ato performativo implacável para os imigrantes de 'color', segundo eles, diferentemente dos seus países de origem” (Messeder: 2007, p. 24).

Para a autora, "o interesse pela mulher negra ou mulata (...) é mais característico dos brancos estrangeiros. E o erotismo associado à 'cor negra', é associada ao gênero feminino, [e] aproxima a mulher negra da prostituta (Messeder, 2007, p. 18). Por isso, posso fazer algumas ligações com as travestis brasileiras enquanto imigrantes na Espanha, participantes ativas no mercado do sexo, cientes da expectativa que têm os clientes espanhóis, mas, sem nenhuma dúvida ou surpresa quanto ao trabalho que vão realizar na Europa, diferente da maioria dos interlocutores de Messeder (2007).

Argumento aqui que as trans ${ }^{17}$ ouvidas nesta pesquisa, em sua maioria, não se interessam em readequar seu sexo, ou seja, realizar a cirurgia de mudança sexual. Pois o intuito é também atender a demanda e a expectativa ${ }^{18}$ (Piscitelli, 2009) da clientela. O que sugere, além do interesse dos brancos estrangeiros

\footnotetext{
${ }^{17}$ Uma outra forma de falar de travetis, principalmente as que circulam no mercado transnacional do sexo.

${ }^{18}$ Em entrevista concedida a Piscitelli (2009) se destaca uma fala que me chamou atenção e pode ser notificada aqui, quando uma de suas interlocutora diz sobre as trans e os clientes: cuanto más estereotipadas, pero con un gran pene y que funcione bien, tienen más salida (Integrante do Coletivo de Transexuales de Cataluña. Entrevista em 30/03/2007.)
} 
como alvo que elas querem atingir, também uma certa ambiguidade da própria figura feminina da travesti, o que faz parte do abanico ${ }^{19}$ de truques que elas tiram dos casacos quando estão em evidência nas ruas ou nos corredores dos pisos, se mostrando para os clientes que as escolhem.

O fator virilidade se destaca e reflete o ideal de masculinidade - tanto hegemônica quanto subalterna -, que marca a figura da travesti, pelo fato de não reassignar seu sexo. Destaco também o fator brasilidade e miscigenação com características na negritude, no caso o mulato - branco e negro -, pelo fato de haver, na literatura e no imaginário, a crença de que, nas senzalas, haviam homens que sustentavam a reprodução de escravos, ou seja, negros mais fortes e mais robustos engravidavam as negras e, com isso, mantinham a produção de escravos, livrando os donos de engenho de comprar outros negros em mercados ou em portos destinados a este tipo de comércio.

\subsection{A AMBIGUIDADE DO CORPO}

$\mathrm{Na}$ Espanha, apenas o anticoncepcional Diane 35 é vendido sem receituário médico, assim como sem distinção de sexo. Segundo as trans, este medicamento contraceptivo não tem um efeito modificador do corpo tão forte quanto o Perlutan ${ }^{20}$ que tomam no Brasil e que não podem consumir, pelo difícil acesso na Espanha. Justificam, por isso, poderem exibir seu membro viril sem problemas. Sobre esse ponto Dra. Cristina, do Cremepe - Recife, (Conselho Regional de Medicina de Pernambuco), me informa:

O que é que acontece no organismo de um indivíduo do sexo masculino se ele for submetido a uma sobrecarga de hormônio feminino? Ele começa a ter no seu organismo uma ação estrogênica que vai fazer com que surjam, ou pelo menos aumentem, os caracteres femininos e uma

\footnotetext{
${ }^{19}$ Leque.

${ }^{20}$ Marca Registrada de Boehringer Ingelheim S. A. Indústria Argentina - Importado por São Paulo. Princípios ativos: Hormônios conjugados.
} 
inibição dos estímulos do hormônio masculino, no caso a testosterona. Se você submete o homem a uma dose de estrógeno, ele passa a afinar a vOz... a vOz fica mais suave, entendeu? É porque no travesti eles afetam muito. Treinam muito. A barba diminui, não desaparece, mas, há uma redução muito acentuada. Começa a surgir o quê? mama, crescimento mamário, que é o que eles mais querem. E na parte genital logicamente que não há um desaparecimento, mas, há uma atrofia, uma tendência à redução testicular e flacidez peniana. Não há como murchar. Então eles começam a ficar mais afeminados. (Dra. Cristina)

Percebo que é por estes traços modificados do masculino que as travestis são identificadas, assim como se identificam, de maneira diferente, no Brasil e na Espanha. É através do uso dos hormônios femininos que a travesti consegue iniciar suas modificações corporais e torná-las constantes, o que geralmente acontece por toda a vida, caso não realize cirurgias mais invasivas, como as de implantes ou aplicações de silicone. Desta forma, sentem falta do Perlutan, e o utilizam aqui

porque é injetável, eu acredito. E eu acho, porque o Perlutan na realidade ele tem um efeito, ele é mais fácil né? Porque se toma uma injeção mensal, em vez de tá tomando todo dia um comprimido (...), porque um dos efeitos colaterais dessa apresentação comercial é retenção de líquido. E dá às vezes turgência mamária, então pode ser que eles achem que o efeito seja mais rápido entendeu? Em termos de mama, isso assim. Pelo fato de reter líquido há um estímulo maior para o tecido mamário, acredito eu né? Não sei porquê. Eu acredito que é por conta do conhecimento banalizado, porque essa apresentação é muito utilizada como contraceptivo principalmente em postos de saúde. Prescreve e não sei se tá distribuindo. (...) $\mathrm{O}$ tratamento hormonal é feito porque o resultado é rápido e é mais barato. $\mathrm{O}$ resultado é rápido assim, na cabeça dele né? Então eles tomam três meses de injeção de Perlutan, daqui a pouco tá aquele, a 
maminha, o peito já doído entendeu? Já fazendo botão. Você vê né? Eles todos orgulhosos com aquele botãozinho. (Dra. Cristina)

Estes efeitos citados são pelas travestis exemplificados e elevados no caso do Perlutan porque a dose que aplicam no corpo é muito maior do que regularmente indica a posologia do medicamento, por isso os efeitos colaterais logo apontam, indicando uma transformação de um corpo agora tenso que passa a inchar - nas mamas e nas ancas -, por causa da retenção hidrossalina, e até mesmo um pouco de sangramento, o que provoca nelas uma felicidade tremenda, já que percebem que os hormônios femininos ${ }^{21}$ estão fazendo o efeito necessário para a transformação daquele corpo.

Uma outra informação importante é que, estando sob medicação, ou seja, com o corpo modificado com o uso de contraceptivos e não totalmente de silicone, "não devem" ejacular, o que as tornam vulneráveis ao ato sexual. Esta vulnerabilidade está vinculada intrinsecamente à modificação corporal quando se investe num imaginário de controle com vistas a atingir um ideal de feminilidade e exclusão de uma masculinidade teimosa em aparecer. A idéia é a de que ao se ingerir hormônios femininos, os hormônios masculinos vão perdendo força e desaparecendo, por isso o imaginário é que devem não apenas tomá-los, mas evitar que o que possa caracterizar a masculinidade saia de dentro do corpo, como se, ao não pôr para fora o líquido espermático, este possa desaparecer sob a grande carga dos hormônios femininos, embora elas tenham conhecimento de que o ato de ingerir hormônios seja uma ação para toda a vida. Isto simboliza, ao mesmo tempo, uma potência e a perda da mesma relacionada ao gênero que se tem e que se pretende a cada dia, pois a idéia da saída de hormônios masculinos, como se pensa, através da ejaculação é uma marca da masculinidade, assim como a própria ereção; por isso o imaginário de seu evitamento. Sobre isso, Dra. Cristina opina:

\footnotetext{
${ }^{21}$ Em conversas com Carol, trans espanhola filha de colombiana, descubro que ela consegue suas doses de hormônios diários através de seu namorado, que é proprietário de um hospital em Madrid.
} 
O hormônio está no sangue deles, o hormônio está circulando. Eles podem ejacular trezentas vezes por dia entendeu? E não vai sair nada. (...) O hormônio, veja só, quando você toma hormônio, e você toma pela via oral, que toma por comprimido, ele é absorvido pelo intestino e cai na corrente circulatória entendeu? Existe umas proteínas em nosso intestino que são carreadoras, são verdadeiros transportadores de hormônios, entre outras substâncias também. Aí quando ela tá transportando o hormônio, ele vai chegando, onde tiver receptor, as células tem os receptores, ele vai acoplando, plac, plac, plac. No esperma não tem hormônio nenhum. O que é o líquido da ejaculação? Espermatozóide no caso do homem, espermatozóide, e uma substância gelatinosa rica em frutose que é pra manter o nutriente do espermatozóide até o objetivo final dele. Ou seja, é uma geléia docinha com o espermatozóide só. Porque qual é a finalidade da ejaculação? Não é a reprodução? A fecundação. Só. Tás entendendo? (...) Agora, pode ir também bactérias vindas de outros quintais, não tem nada a ver com algum tratamento. (...) Mas, fisiologicamente só tem uma finalidade: reprodução. O prazer é outra história. Que pode ser obtido com ou sem ejaculação, por isso que homens que têm cirurgias, que retiram próstata... a próstata e as vesículas seminais que acumulam líquido, muitas vezes tem uma relação sexual sem a ejaculação, ou muito pouquinha e não deixam de ter orgasmo, prazer. Ali não tem hormônio nenhum. Ele não tá perdendo nada com aquilo ali.

É interessante questionar o porquê das travestis terem esta característica de mostrar o pênis com mais facilidade nas propagandas que fazem de si na internet e nos periódicos espanhóis. No Brasil não há um destaque neste ponto, em sua apresentação. É uma forma de explicitar o quão diferente é o mercado do sexo por lá e por aqui, como também não se faz necessário ficar tão explícita a ambigüidade da travesti brasileira no Brasil, pois lutam mais por uma feminilidade do que pela afirmação de identificações em meio do caminho. 
Desta forma, na Espanha, elas acabam por expor o que mais se destaca em sua figura: a ambigüidade do corpo. Poderia também mencionar a completude que muitas fazem questão de expor nas falas, o que se expande em jornais, ruas e sites de relacionamento, principalmente por ser um atrativo para os próprios clientes que as procuram em busca de seu desempenho sexual através do uso do membro viril.

Nos anúncios no Recife, as informações não dão destaque aos membros sexuais delas, como vemos:

\section{DAYANNA DIAZ}

Travesti insuperável loira bela feminina olhos verdes corpo escultural turbinada bronzeada beijo grego ${ }^{22} \mathrm{c} /$ loc [sic] $3232323232^{23}$

BELA KARINA - Travesti feminina perfeita quase mulher com local [sic] 3232323232/969696969

TATY TRAVESTI - Gata de luxo Ex miss 9696969696

TRAVESTI - Uma deusa estilo Barbie morena R $\$ 250$. www.allina.com.br F: 9696969696

(Jornal do Commércio do Recife, 03 de outubro de 2007)

Desta forma, ser brasileira lá é diferente de ser brasileira aqui. Para as trans, o fator de acesso a tecnologias de controle hormonal e modificação corporal, disponível em farmácias, explica boa parte destas diferenças. Mas, também a nossa origem, como já relatado por Geysa Mya no Eros Guia, o que indica sermos miscigenadas - de índios, negros e europeus -, molda-as como pessoas que podem as duas coisas, têm poderes que só alguns seres

\footnotetext{
${ }^{22}$ Beijo no ânus acompanhado de carícias. A prática oferecida pelo(a) anunciante faz parte da ambiguidade que a relação entre travesti e cliente oferece.

${ }^{23}$ Todos os números de telefone foram modificados para não comprometer as anunciantes, já que não pedi a elas autorização para divulgar seus anúncios aqui. O site disposto no último anúncio também foi modificados para evitar qualquer problema.
} 
mitológicos ou transexuais poderiam, ter, como diria Hélio Silva (1993), tentando mostrar que, na verdade, não se trata de colocá-las no patamar de animal mitológico e, sim, de "inscrevê-los no circuito do humano, retirá-los da vitrine viária, da terra encantada onde florescem fadas e monstros, para situá-los no contexto de onde pode emergir o sentido e o afeto"(Silva, 1993, p. 82).

O anúncio também acaba por manter a exotização via animalidade, que muitos de nós, estudiosos e ativistas da temática nos preocupamos tanto em extinguir, mas o campo, muitas vezes, aponta para sua confirmação. Principalmente já desenvolvido por outros autores, como Piscitelli (2009), que afirma:

"Em primeiro lugar, as imagens envolvendo brasileiros/as que circulam através das fronteiras não reiteram necessariamente aquelas que, produzidas no Brasil, foram utilizadas para difundir o país no exterior, inclusive em propagandas oficiais, até poucos anos atrás. Um exemplo é oferecido pelas imagens que circulam em Portugal, em que as mulheres, independente da cor da pele, são tratadas como mestiças porque sua brasilidade já lhes confere esta filiação. Essas imagens tendem a ser erotizadas por meio de uma construção de nacionalidade que é sexualizada, mas não está de forma inevitável associada às "cores" de pele escura. Nesse sentido, tais imagens apontam para a racialização/ sexualização da nacionalidade, marcada por gênero, e não para a sexualização da "raça". Em segundo lugar, os significados atribuídos à "etnicidade brasileira" diferem em diversos contextos migratórios. Igor Machado, em uma observação que compartilho, chama a atenção para a existência de processos de exotização diferenciados, de acordo com as sociedades de recepção dos migrantes. Para compreender esses processos, é importante levar em conta as relações históricas de tais contextos com o Brasil." (Piscitelli: 2009, p. 3-4). 


\subsection{O FAZER A EUROPA: DIREITOS E ACESSOS}

Em conversas com Cris Falcão, no Recife, ela me afirma que todas vão "fazer" a Europa. Penso que esta assertiva significa trabalhar, ganhar dinheiro, conhecer e trazer novidades, como experiências, roupas, performances para shows e histórias para contar, além de ainda poder estar de volta para casa, dentro de um período relativamente curto (Urry, 1999). Senão, com dinheiro para comprar uma casa nova, como muitas desejam e conseguem. A Europa está por fazer porque ainda é desconhecida para quem vai até ela, o mesmo diria o conquistador das terras dantes apenas conhecidas por índios na época dos descobrimentos.

$\mathrm{Na}$ Espanha, é fácil acessar essas descobertas, em termos de novidades, para que constituam notícias no retorno ao Brasil. Basta apenas circular pelas ruas e falar um pouco do castellano. Esta autonomia na linguagem é conquistada simplesmente conversando com os pares, outras travestis e transexuais, ou mulheres que também trabalham com a prostituição e são atendidas por organizações governamentais e não-governamentais e com isso são informadas de seus direitos no país. Estes direitos são reforçados, por um lado, por uma busca de cidadania para quem deseja se firmar na Espanha, ou mesmo ter mais segurança obtendo os documentos necessários.

Penso cidadania aqui em consonância com o conceito de Carvalho que afirma ser esta um

"fenômeno complexo e historicamente definido (...) [o que] inclui várias dimensões e que algumas podem estar presentes sem as outras. Uma cidadania plena, que combine liberdade, participação e igualdade para todos, é um ideal desenvolvido no Ocidente e talvez inatingível. Mas, ele tem servido de parâmetro para o julgamento da qualidade da cidadania em cada país e em cada momento histórico (Carvalho, 2002, p. 8-9). 
Ser cidadão pleno é ser titular de direitos civis ${ }^{24}$, políticos $^{25}$ e sociais ${ }^{26}$. Desta forma, as travestis, no Brasil, têm reduzido acesso aos três direitos, por não conseguirem alcançar, em sua maioria, por exemplo, uma formação em educação, disponível a todas as outras pessoas e, como direito social, um "pré-requisito para a expansão dos outros direitos" (MARSHALL, 1976 Apud CARVALHO, 2002: 11). No Brasil, este direito, o social, precedeu os outros, assim como em vários países.

Para as interlocutoras, ter uma educação formal, que lhes foi impedido devido à discriminação na escola, é condição sine qua non para alcançar um emprego distinto, a fim de que não se sintam ameaçadas em sua integridade enquanto cidadãs. Por esta exclusão desde cedo acabam por firmarem-se à margem da sociedade em termos de acesso a um trabalho formal, o que constitui direitos adquiridos.

$\mathrm{Na}$ lista a seguir, compilada por esta autora, através de informações em ONGs e OGs, e panfletos recolhidos em locais de assistência a imigrantes, estão relacionadas as oportunidades que os migrantes podem acessar estando na Espanha:

Saúde: Todas as pessoas têm o direito de acessar o sistema público de saúde, desde que se cadastrem no Posto e façam sua Carteira sanitária. Para quem não quer se identificar, caso não esteja legalizado no país, há atendimentos em postos de saúde que não pedem identificação e documentação alguma, apenas que você se comprometa a ir buscar os exames realizados, mas mesmo assim fica a critério do paciente. Algumas ONGs (Fundación Triángulo, Hetaira, Aprampt,) vão às ruas, bares e pisos e fornecem preservativos a garotos,

\footnotetext{
24 "Direito fundamental à vida, à liberdade, à igualdade perante a lei. Se desdobram na garantia do ir e vir, de escolher o trabalho, manifestar o pensamento, organizar-se, ter respeitada a inviolabilidade do lar e da correspondência, de não ser preso a não ser por autoridade competente e de acordo com as leis, de não ser condenado sem processo legal regular. Direitos baseados na existência de uma justiça independente, eficiente e acessível a todos". (Carvalho. 2002, p. 9)

${ }^{25}$ Direito que se refere a participação do cidadão no governo da sociedade. Seu exercício é limitado. No Brasil pode se limitar ao direito do voto. (Carvalho. 2002, p. 9)

${ }^{26}$ Garantem a participação na riqueza coletiva. Direito a educação, trabalho, salário justo, saúde, aposentadoria. Podem existir sem os direitos civis e políticos, em tese, embora seu alcance, sem os outros, possam ser arbitrários. (Carvalho. 2002, p. 9)
} 
trans e mulheres, embora na Espanha seja muito difícil ser veiculada alguma campanha de uso de preservativo na mídia televisiva.

Alimentação: Obras sociais, ordens religiosas, irmandades e outras associações ligadas à Igreja Católica oferecem comida pronta todos os dias. Em algumas igrejas não católicas se oferecem alimentos para levar, caso a pessoa não tenha como comprar durante o mês e seja fiel daquela instituição religiosa.

Alojamento: Albergues oferecem descontos abaixo de qualquer tabela; igrejas e associações oferecem camas de graça para um número determinado de pessoas dormirem todos as noites, por ordem de chegada. Há espaços que recebem pessoas especificamente no inverno, haja vista que neste período do ano os casos de problemas com mortes de moradores de rua aumentam. A Cruz Roja (Cruz Vermelha) espanhola também está disponível todo o tempo para alojamento.

Banhos: Há espaços onde se pode tomar banhos públicos. Estes não são os mesmos onde se dorme nem onde se come gratuitamente.

Roupas: Nas igrejas e centros sanitários se distribuem com uma certa periodicidade roupas para a população necessitada. Há ONGs que dispõem de peças para as pessoas buscarem na hora que quiserem. Também se encontra, em qualquer esquina, peças de roupa usadas, sapatos e acessórios novos e usados de qualquer estação. Basta ter coragem para lavar e usar. Não apenas roupas, como também televisão, rádio, colchões, lençóis, travesseiros, camas, móveis em geral, brinquedos, tudo se encontra no lixo da Espanha.

Trabalho e Formação: Algumas Associações destinam-se a formar jovens, imigrantes, refugiados, sem cobrar taxa alguma. Estas associações podem ou não estar associadas a prefeituras, ONGs, países coligados, como a República Dominicana, e o Sindicato dos Trabalhadores.

Atenção Social e Jurídica: Associações de refugiados e imigrantes, programas da prefeitura de Madri, Ministério do Trabalho e Assuntos Sociais oferecem acessoria jurídica gratuita e serviços de profissionais habilitados em atenção social.

Aulas de Espanhol: Associações como a Muçulmana de Madri, Vomade, OSRR, Karibu-Africanos, SOS Racismo Madri e Asti Madri oferecem cursos 
gratuitos a imigrantes que procuram trabalho na capital. Algumas destas associações oferecem outros cursos, como empreendedorismo e aulas de costura e cabeleireiro.

Internet: Há um centro de acesso público e gratuito à internet (Capi) que funciona todos os meses do ano, exceto em agosto.

Além disso, a prefeitura de Madri tem um programa - Programa de Información y Atención a Homosexuales y Transexuales de la Comunidad de Madrid -, que ajuda as pessoas a conseguir emprego, pagar aluguel, fornecendo uma parte do valor e ainda conseguindo um lugar ${ }^{27} \mathrm{com}$ um preço acessível para a realidade da pessoa. Há uma agência pública de aluguel que intermedia apartamentos e quartos, com preços acessíveis para jovens e pessoas que justifiquem não poder pagar o valor do mercado. Madri ainda oferece os Centros de Día para idosos, moradores de rua ou imigrantes.

Muitas das trans não acessam os serviços oferecidos para as pessoas em situação irregular, em sua maioria imigrantes. Acredito que isso ocorra por medo ou e pela falta de tempo, já que estão na Espanha se dedicando integralmente ao mercado do sexo.

O que fica vislumbrado, além dos que acabei de listar, são outras possibilidades de Europa: parques, boates, pessoas, cafés, lojas, grifes em beleza de roupas e jóias. A experiência das interlocutoras me possibilitam entender que a viagem das travestis para a Europa tem um componente muito forte de busca de prestígio e reconhecimento, como se fosse uma viagem turística (Graburn, 1975). Afinal, esta é a condição delas ao saírem do Brasil com destino à Espanha.

Como turista, cada uma delas tem consciência de que "está num lugar e num tempo especiais, e que por isso precisa aproveitar o máximo daquilo que está vendo como sagrado e diferente" (SCOT'T, 2006). Embora este aproveitamento possa apenas ser vivenciado em momentos de férias do trabalho que realizam por lá, ou seja, depois de pagar a dívida contraída pela

${ }^{27}$ Programa Provivienda, dirigido a população de imigrantes, regulares ou irregulares. Agência Municipal de Alquiler, dirigida a qualquer pessoa que precise do serviço. Além disso, há as redes informais de ajudas, os amigos e pisos onde as trans fazem programas e pagam parte do que ganham para estarem dormindo e comendo por lá mesmo. 
sua viagem e de 21 em 21 dias dispostas em pisos, ocasião em que podem viajar para outras cidades com o intuito apenas de passear, fazer compras e tirar fotos. Elas estão participando de "coisas extraordinárias" quando estão fora de casa, tornando-as distintas, como afirma Graburn (1975):

Fundamental is the contrast between the ordinary/compulsory work state spent 'at home' and nonordinary/voluntary 'away from home' sacred state. (Graburn, 1975, p. 452).

Few tourists come home from a vacation without something to show for it, whether it is matchcovers, folk art, or rolls of exposed film. (Graburn, 1975, p. 459)

Desta forma, as travestis enviam as fotografias como imagens de seu sucesso, bem como comprovadoras da experiência prazerosa (Urry, 1999) que estão vivenciando na Europa. Elas demonstram através das imagens que estão em um lugar onde a magia do turismo pode ser acessada por elas. São fotografias para a família e amigos que, como cartões postais, têm o objetivo de impressionar aqueles que as recebem. (Graburn, 1975, p. 460). Uma tendência clara para adoçar a experiência que nem sempre, nem completamente, é feliz, principalmente pelo próprio trânsito entre cidades e pisos.

Alguns acessos que se traduzem para elas como "facilidades", como por exemplo o fato de verem e poderem conhecer celebridades antes vistas apenas em filmes e telenovelas, contribuem para que as meninas continuem voltando à Espanha sempre que lhes aparecem oportunidade, "para ganhar mais um dinheirinho", porque "dinheiro e os homens mais belos do mundo" (Palova), é o que move o grande moinho da atração chamada Europa. Como afirma Cris Falcão sobre seus circuitos diversos na Espanha:

Na Espanha eu trabalhei em três lugares, né? Foi em Madri, (...) em Barcelona e nas Ilhas Canárias. Trabalhei em 
discotecas, fiz lap dance ${ }^{28}$ né? Que é com, trabalhando naquela... dançando. Só é duro porque a gente tem que trabalhar, às vezes são duas horas seguidas ou quatro horas seguidas, entendeu? Ali em cima, ai você fica... bem cansativo, mas é legal... é interessante. As pessoas são bem diferentes, né? Também, porque é outra cultura né, a Espanha. Mas é um país lindíssimo. Eu viajei um pouco pelas cidades e gostei. Agora só são meio ruinzinhos assim.....em relação a, ao trabalho, né? Em relação a pagamentos porque, como a gente trabalha, não é muito a coisa legalizada, na Espanha tem muito trabalho no negro, né? Então os patrões às vezes gostam de... de botar uma coisa no papel e pagar outra, mas... normalmente, no mais, bom que é um país que aceita o casamento homossexual, então, não tem tanto preconceito, né? A Espanha é mais liberal e tudo, você vê, tem boates que funcionam até o meio dia. (Cris Falcão)

Por isso, a Espanha está tomada de imigrantes vindos de todos os locais do mundo. Ao todo, no ano de 2007, esta realidade abrangia "166 nacionalidades convivendo em Madrid" 29 e a cada dia chegam mais: em balsas - ayucos $^{30} \mathrm{da}$ África; em ônibus, trens, aviões de todos as direções do mundo, com pessoas em busca de novas oportunidade de vida, de trabalho e diversão passageira, quiçá, um novo mundo à vista. As novas medidas que as autoridades espanholas estão tomando atualmente, em vista da entrada em massa de imigrantes, também repercutem de forma negativa na entrada e permanência das trans no território espanhol, quando passam a seguir as normas globalizadas dos aeroportos e de seus funcionários apontando a sua condição.

\footnotetext{
${ }^{28}$ Faz parte de um estilo musical e dança (junção entre blues e tecno - música eletrônica) onde o(a) dançarino(a) se apresenta em um local específico no clube noturno, podendo ser uma gaiola ou outro local de destaque no ambiente de diversão.

${ }^{29}$ Gabriel Fernandes é Representante Conselheiro de Imigração da Comunidade de Madri. Obtive esta informação em uma reunião para o lançamento da obra Estudio Sociológico y Jurídico sobre Homosexualidad y Mundo Islámico, de Lola Romero Martin, Manuel Rodenas Pérez e Fernando Villaamil Pérez. Editado em Madri, por Cogam, Felgt. Em junho de 2007.

${ }^{30}$ Balsas feitas de material plástico inflável utilizados geralmente como barco salva-vidas nas grandes embarcações.
} 


\subsection{A CIDADE DE MADRID: LUGAR DE PASSAGEM}

Madri surge como cenário para as travestis enquanto rota, muitas vezes de meio do caminho, entre muitos lugares onde circulam, e acaba sendo para muitas, principalmente as que saem do Recife, lugar referência de Europa. Ela desperta o interesse das trans por ser uma cidade capital, em um país que luta por direitos na diversidade, cidade que luta, desde seus primórdios, por renovação e reformas urbanas constantes ${ }^{31} \mathrm{e}$, como capital recente de um país pouco acostumado com a democracia e com a diversidade, vive hoje uma explosão cultural, em que lutas políticas de interesses divergentes entram em conflito, acarretando terrorismos e atentados.

A cidade é geograficamente central no país, e por isso rota e lugar de passagem para muitos transeuntes. Assim como são muitos dos destinos das travestis brasileiras, o que reforça sua maneira de inserir-se no mundo e garantir, com isso, o reconhecimento que tanto almejam. Reconhecimento este ratificado pelo tornar-se legítimo - enquanto pessoas de direito (Honneth, 2003), objetivo a que elas se direcionam.

A história da cidade se entremeia entre o catolicismo forte no país, as festas diversificadas com touros e as sucessões reais. Mas estas informações ficam atrás, nas fotografias de parques e monumentos que visitam quando estão de folga.

Para as travestis, conseguir trabalhar na Espanha só é possível porque elas estão de passagem por aquele continente, o mesmo que acontece quando realizam suas viagens pelo Brasil, seja São Paulo, Rio de Janeiro ou outro estado do país. Até mesmo Campina Grande é vantajosa quando passam um tempo sem aparecer por lá, contanto que não permaneçam muito tempo naquela cidade. Circulando, elas trazem malas cheias de novidades de um outro mundo e se sentem cada vez mais inseridas no mercado do sexo que as ocupa como trabalhadoras, embora não cidadãs.

\footnotetext{
${ }^{31}$ Assim como as travestis impõem a seu corpo reformas constantes para melhor se apresentarem e manter-se jovens.
} 
Desta forma, o que perpetua a mobilidade delas na Europa é a possibilidade de estarem no mercado de trabalho, aliado ao fato de poderem participar da cultura do lugar onde estão circulando, e super dimensionar esta experiência, para circular mais entre países.

\subsection{AS DESVANTAGENS DA EUROPA}

A Europa não aparece apenas como lugar vantajoso para quem migra. Mesmo que no imaginário das travestis brasileiras haja um ideal de perfeição identitária, segundo o qual, para ser uma travesti completa é importante ir para a Europa, as dificuldades aparecem automaticamente ao se pôr os pés fora do Brasil. Desta forma, pensar o lado negativo, das viagens e da estada na Europa, é também um ponto importante a ser discutido na trajetória das travestis que para lá se destinam.

As migrações devem acontecer, primeiro porque, segundo Morgan, "sair da cidade dá status, voltar significa mostrar que venceu na vida". Um sonho que perseguem desde que decidem pela travestilidade.

As travestis que não conseguem acessar a Europa, afirmam que lá a experiência não é tão feliz como dizem as que voltam exaltando as belezas e novidades do primeiro mundo. Percebe-se que o discurso tem um certo inconformismo, revelando o desejo de um dia estar naquele continente ou apenas ressaltar a experiência negativa das colegas. Destaco o segundo caso:

Umas morrem na Europa; umas pegam doença lá, com medo da família descobrir elas ficam por lá mesmo na Europa, se contaminando mais até morrer; umas é assassinada lá, que lá também têm violência que é verdade, né? E muitas fica lá. Fica lá até... até Deus levar. Eu tenho uma amiga minha que viajou pra Suíça, Bina, morreu na Suíça. Ficou lá o corpo dela, porque você sabe, trazer o corpo pra cá, a família sem condições... Comprou apartamento lá em Pau Amarelo, não, no Janga, foi, comprou um apartamento no Janga. Tirou a mãe do aluguel, mas também morreu lá. Ela disse a mim: "Roberta, eu vou 
morrer na Europa, eu não quero morrer no Brasil não!" (Roberta)

Falas como a de Roberta justificam a permanência de muitas delas no Brasil, assim como em alguns casos das que ficam na Europa de forma definitiva.

É importante afirmar aqui que o retorno é um fato comum na experiência do migrante e as travestis não poderiam fugir da regra por se reconhecerem também através desta identificação. $O$ fato de estarem circulando pela Europa tem também muitos pontos negativos, como descritos por Roberta; assim como a discriminação que sofrem triplamente por serem garotas de programa, imigrantes ilegais, em sua maioria, e travestis. Uma carga de estigmas que só a própria circulação contribui para que elas arranjem um “jeitinho" (Da Matta, 1989) de driblar as "saias justas” (Pelúcio Silva, 2007) em que podem se encontrar.

Ou seja, é a circulação das travestis, como produto da discriminação na família, na escola e no mercado de trabalho - discriminação esta que as faz alcançar conquistas menores em relação a outros coletivos considerados minorias, como por exemplo, as lésbicas e os homossexuais -, o que oferece a elas "uma existência social" (Butler, 1997), ou seja, uma oportunidade de estarem inseridas no mercado que conhecem muito bem desde jovens, e como brasileiras são educadas culturalmente para sairem "driblando" quando em situação difícil.

Mais sobre aspectos negativos dissertarei no item a seguir, que destaca a perspectiva de dois espaços de trabalho, o piso e as ruas, o que sugere dois ambientes de análise, o aprisionamento e a liberdade presente nos espaços através da trajetória de Érica e Byanca.

\section{7 ÉRICA E BYANCA}

As informações destas duas interlocutoras são importantes porque alimentam o argumento de que a Espanha é um local bom para travestis 
brasileiras conseguirem melhorar de vida. Todavia, possui variadas formas de inserção do migrante, principalmente em termos de ocupação no mercado do sexo.

O encontro fora combinado às 17 horas, levei um tempinho para chegar ao local, pois ainda buscaria Érica na pensão da Hortaleza e caminharíamos até a boca do metrô Tribunal. Chegando lá, Byanca foi logo dizendo que, se dali a 15 minutos não chegássemos, ela iria embora. Nunca costumo atrasar, nem tampouco na Espanha, mas como confiei no atraso das duas, acabei por deixar Byanca um pouco irritada. Pedi desculpas enquanto as apresentava e fomos ao café Gambrinus.

Érica e Byanca trocaram ali histórias, enquanto as observava, entrando na conversa de vez em quando. As duas trans têm trajetórias diferentes, embora sejam brasileiras em Madri. As realidades o tempo todo se chocavam em relação à construção da trajetória de vida de cada uma.

Érica foi para Espanha com seu próprio dinheiro e com um mês de estadia mandou buscar Roberto, com quem conjugalmente vive até hoje. Byanca informou que foi "cafetinada" por uma colega, conterrânea sua, que já conhece bem a Espanha, principalmente Barcelona, local de seu desembarque. Ela pagou seis mil euros $(\bullet 6.000,00)$ referentes à viagem, contatos e aprendizado sobre o lugar: as ruas, os pisos e os comportamentos pois, sem estes, não seria possível estar em um país estrangeiro. Essa sua amiga ainda lhe forneceu uma carta de invitación, carta-convite escrita por seu companheiro espanhol, que Byanca recebeu no Brasil e levou na bolsa, apresentando para as autoridades na entrada à Espanha:

Elas cobram e você vem se você quiser. Eu precisei vir para mudar um pouco e fazer minha vida né? Porque no Brasil a gente não consegue, só dá pra comer e comprar as coisas [básicas] mesmo. A carta diz que eu poderia entrar no país dele pra visitar. Ele me convidou pra ficar seis meses na casa deles. É tanto que quando chega lá eles vão olhar a carta, vão ver o nome da pessoa, vai ver o telefone da pessoa e ligam pra pessoa pra ver se é verdade, se a pessoa tiver de acordo comigo ele vai dizer: Não, é. Pode deixar 
passar! Agora se ele disser não: Não sei nada disso! Ali, dali mesmo eu sou deportada, já nem entro. Mas, como era ela, ele já era casado com ela e tal, ele gostava dela, ela pediu a carta e explicou tudo pra ele: quanto que eu ia pagar e tal... (Byanca)

Érica faz constantemente viagens para outras cidades espanholas, assim que muda a estação do ano. Nelas realiza trottoir, e anuncia-se em periódicos locais. Byanca, com exceção de Barcelona, só trabalha em pisos (locais fechados, apartamentos), o que lhe proporciona mais segurança porque a polícia não vai no piso se não houver denúncia e, assim como a Espanha, "só se comportar que a polícia não toca na gente. Agora as que são devassas, eles pegam e botam presa”. (Byanca)

Érica está junto com Roberto desde os 13 anos de idade, ou seja, há 10 anos. Ambos foram para a Espanha em 2005, janeiro e fevereiro, respectivamente. Byanca está solteira. Seu namorado, que também estava na Espanha, como garoto de programa, foi deportado para o Brasil e "está dando um tempo" (Byanca) para retornar àquele país. Durante a conversa, ela afirmou que está tentando acordo com uma espanhola, para casamento, o que lhe proporcionará lospapeles.

Érica trabalha na Calle Castellana, uma das vias mais importantes de Madri, para trottoir. Byanca afirmou categoricamente não ter coragem de fazer pista nesta cidade, pois tem receio de estar nas ruas pela possibilidade da polícia nacional the prender, devido ao seu prazo de estada ter expirado no passaporte.

Érica fala com uma certa tranqüilidade sobre suas cartas de expulsão, devido a prisões ocorridas na rua onde faz trottoir, principalmente por saber que quem possui uma delas não pode ser preso por estar irregular, sofrendo, no máximo, com o vencimento de sua carta, o recebimento de outra, que vão se acumulando na bolsa e servem de documento para que não seja mais presa. Vale ressaltar sua última prisão, que durou 80 dias, por acusação de tráfico de seres humanos, sendo absolvida por falta de provas que legitimassem o fato de sua reclusão. Ela foi ao encontro marcado com Byanca, que nada 
sabia sobre os motivos pelos quais Érica buscava sair das ruas de $\mathrm{Madri}^{32}$, pois, de antemão, esta gostaria de conseguir um piso para trabalhar, embora sua situação de companheira de Roberto a faria ter mais gastos do que ficando numa pensão com diária de trinta euros $(\bullet 30,00)$, sem direito a comida, e ir às ruas no horário que lhe conviesse, o que não poderia se estivesse em pisos, cujas regras são rigorosas, principalmente para quem está acostumada com a liberdade das ruas; no entanto, é mais seguro para quem, por exemplo, está em situação irregular no país estrangeiro.

\subsubsection{PRISÃO OU LIBERDADE?}

Uma grande diferença nas duas histórias de vida, o que não ajuda Érica a conseguir um piso nem Byanca a ir para a rua, é a força que as categorias dicotômicas aprisionamento/liberdade ganham com a experiência de ambas. Ser livre é o que buscou Byanca com a sua ida à Espanha. Ser livre é o que também busca Érica, desde que saiu de casa no Maranhão junto com seu companheiro aos treze anos de idade para viver "no meio do mundo" 33 .

Érica foi para a Espanha porque outras travestis brasileiras lhe informaram que neste país a polícia não persegue, não expulsa e depois de quatro anos você pode obter visto de residência, o que está difícil, haja visto as cartas que obteve com suas prisões. Ela apenas gostaria de conseguir terminar a casa da mãe em Anápolis, o que gerou sua ida àquele país.

Liberdade é o que muitas buscam ao embarcarem para outro país, como defendeu Romero em estudo sobre homossexualidade de garotos islâmicos na Espanha. Não apenas uma liberdade financeira ${ }^{34}$. Liberdade

\footnotetext{
${ }^{32} \mathrm{Um}$ dos motivos foram as brigas entre travestis brasileiras e espanholas na Calle Castellana, o que fez com que houvesse também um deslocamento delas para a Desengaño, principalmente as espanholas. E algumas brasileiras para a Gran Via.

${ }^{33}$ Na verdade, esse "no meio do mundo" exatamente significa morar nas ruas, até chegarem em São Paulo, o que depois de um tempo, com a ida da mãe de Érica para Goiás, se concretizou no acolhimento do casal por esta, que já estava separada do marido.

${ }^{34} \mathrm{Ou}$ seja, uma folga no bolso para poder investir no corpo, na compra de sua moradia, no retorno à família, ao país e aos pares.
} 
também em relação a se sentirem bem consigo mesmas, pelo fato de terem dado certo na vida e conseguido migrar para um lugar distante, onde os problemas de seu lugar de origem não as atingem diretamente.

A dicotomia prisão/liberdade aparece o tempo todo nas comparações que fazem acerca dos lugares onde batalham: em pisos não se pode receber visitas, nem morar com o companheiro, a não ser que ele seja também garoto de programa e o piso concorde em admitir os dois. O tempo que as trabalhadoras de piso têm para ficar fora são algumas horas por dia, ou noite, determinado pelo funcionário encarregado do ambiente. Este tempo, segundo Byanca, pode ser das 2 até as 10 horas da manhã, período este em que elas vão a boates - local onde conheci muitas delas -, bares e revêem as amigas, para dasabafos e novos contatos.

Neste sentido, rua ou piso têm suas especificidades, que pressupõem ora liberdade, ora aprisionamento. Ficar em um piso ou em locais abertos (ruas, praças e parques) tem suas regras. Estas sempre indicam que o trabalho realizado ali é passageiro, por isso é tão importante a submissão às regras, principalmente pelo fato de poder naquele espaço retornar para realizar a mesma atividade.

Liberdade é algo que elas procuram mas, devido ao sonho maior de "fazer a vida" com o dinheiro conquistado na Europa, elas adiam para quando voltarem ao país origem todo um sonho de viver com o prestígio e a renda obtida.

Estar "presa” em pisos dá a impressão de segurança e permite, além de ganhos financeiros, circulação dentro das próprias regras estabelecidas em tal atividade e estabelecimento. Assim como estar "livre" nas ruas, pressupõe estar à mercê da vigilância que prende, estar disponível ao olhar da polícia e de outras pessoas que cerceiam esta suposta liberdade.

Foi o receio de outros "aprisionamentos" o motivo de Érica não ter ficado animada em continuar sua busca por pisos. Juntou-se o que ela já escutara de suas colegas com a confirmação de Byanca sobre o tempo limitado que têm as travestis que trabalham em pisos para circular no espaço da rua, além de seu relacionamento amoroso, para fazer Érica desistir da idéia de mudar o local de trabalho. 
Ela sabe muito bem dos "truques" que utiliza para se dar bem no frio das ruas de Madri, na Calle Castellana ou na Desengaño $0^{35}$, em que se posicionava já no final da pesquisa, ou mesmo perto da Gran Via, nas proximidades da Telefónica, junto com Yuri ${ }^{36}$.

Truques estes que a torna mais uma na multidão oriunda de todo o mundo, que circula por ali, o que a invisibiliza dentre tantas mulheres de tantas nacionalidades que esperam alguém nas calçadas, nos cafés, nas escadarias do metrô ou mesmo na esquina da rua em que estava localizada o hostal onde Érica morava com Roberto.

Truques como, por exemplo, falar ao celular para despistar alguém que desconfia dela estar em trottoir, quando passa uma ronda da polícia; dar uma volta pelo quarteirão para comprar uma coca-cola ou mesmo ir à banca de revista da esquina pegar um periódico que está sendo oferecido gratuitamente para desnortear alguém que possa incomodar seu trabalho diurno ou noturno, já que na Espanha não há horário determinado para estar nas ruas fazendo trottoir; mudar sempre de calçada, de rua, de amigos ou de horário para não ser perseguida pela polícia que tem Comisaria (Delegacia) a duas quadras dali. Truques que indicam uma liberdade vigiada das travestis que circulam em busca de uma cidadania, no lugar que escolheram para viver e trabalhar, pelo menos por um tempo. Cidadania esta cercada por ameaças de todos os lados.

Ao mesmo tempo em que se pode ter toda uma segurança quando se está dentro de um piso, pelo fato da polícia não importunar, a situação configura-se como um aprisionamento, em que as horas para comer, sair, ter

\footnotetext{
35 A Calle Castellana é uma das avenidas importantes da capital espanhola. Fica localizada no eixo leste-norte de Madri. A Calle Desengaño se localiza transversalmente à Gran Via, a mais central da cidade, logo assim com posicionamento privilegiado para quem quer se direcionar para o bairro de Chueca, bairro historicamente boêmio e considerado bairro gay de Madri.

${ }^{36}$ Brasileira que estava na Itália e recebeu carta de expulsão. Foi para Madri e conheceu Érica que lhe levou para a pensão, onde mora com o marido, e a desceu para a avenida para lhe ensinar os truques de se viver o trottoir na capital espanhola. No final da pesquisa já estava com carta de expulsão também da Espanha.
} 
seu quarto e seu parceiro fixo são delimitadas pelo responsável pela atividade, pela chegada de clientes e pelo espaço disponível para cada uma ${ }^{37}$. Além de que, em pisos, a metade do que se ganha vai para o estabelecimento, enquanto na rua é todo dela.

Mesmo com toda uma suposta liberdade vivenciada nas ruas onde se desenvolve trottoir em Madri, as travestis brasileiras já iniciaram lá alguns comportamentos característicos das zonas de trottoir no Brasil: as cobranças de taxas de permanência no ponto. Érica me afirmou ter pago mil euros $(\bullet 1.000,00)$ a uma outra brasileira, também travesti na Calle Castellana, e creio que foi este o motivo dela ter migrado de zona.

O medo maior de se ficar nas ruas, parques e estradas da Espanha é a falta de documentação, o que pode acarretar encarceramento por horas, como ocorreu com Érica e Yuri, pois quando a polícia pediu a documentação que comprovasse a legalidade de ambas, em momentos distintos, não puderam entregar os ditos documentos, por não possuí-los: os passaportes estavam com as datas de retorno vencidas há muito, o que quer dizer que há mais de três meses deveriam ter retornado ao Brasil.

Assim, vão vivendo de "truques" para entrar na Espanha e permanecerem tentando despistar a polícia, como já relatado anteriormente. $\mathrm{O}$ que faz inferir a experiência delas como uma mescla de vantagens e desvantagens que só são justificadas pelo jeitinho e a necessidade de estar incluídas num mundo globalizado, no que tange ao trabalho e ao que o dinheiro conseguido com a atividade pode proporcionar.

\subsection{SER EUROPÉA}

Neste ponto, destacarei como as travestis entendem-se como européas, identificação que está moldada por um habitus travesti, percebido quando

\footnotetext{
${ }^{37}$ Em conversa com Diogo, fico sabendo que no piso em que ele trabalhou apenas o espaço da cozinha era comum aos garotos e travestis que ali trabalhavam por um período de 21 dias. Ali eles comiam, quando não havia nenhum cliente na casa, e se reuniam para dormir, já que os quartos eram destinados aos encontros com clientes.
}

Temáticas, Campinas, 20(40): PG-PG, ago./dez. 2012 
elas passam a classificar suas atitudes e descobertas pelo fato de terem ido trabalhar e vivenciar o mundo da Europa.

Ser européa não significa conseguir os documentos de naturalização na Europa, embora muitas travestis brasileiras ${ }^{38}$ persigam este ideal de identidade para melhor circular entre o Brasil e os países daquele continente.

Européas são as travestis que circulam entre Brasil e Europa, no caso a Espanha, e conseguem trazer de lá novidades para as que não foram ainda, principalmente marcadas em fotografias, roupas e discursos. Com isso, conseguem "fazer as cabeças" das mais jovens, iniciantes na travestilidade e, através de esquemas de ajuda, conduzir novas travestis para o mercado do sexo europeu.

O fato de ir à Europa gera capital cultural e econômico, não apenas para as travestis brasileiras. Assim como ser amiga de européa gera prestígio, constitui um veículo de aprendizado e a possibilidade de futuras viagens.

Européas são as que se distinguem dentre as demais, não necessariamente as mais jovens, e sim as mais experientes dentre as travestis, porque viajadas e conectadas com um mundo globalizado que lhes confere. O conhecimento da linguagem do mundo europeu em termos de trabalho com o sexo trottoir piso ou clube -, não há diferenças, pois o importante é "sair da cidade" para alcançar "status, e mostrar que venceu na vida" (Morgan). A cidade é apenas uma referência de lugar em qualquer território, seja nacional ou internacional. Como afirma Grazita:

... ser europeia é trabalhar na Europa e ser glamurosa, como algumas acreditam ser!!! Acredito que uma vez que vc foi, será sempre considerada europeia. (Grazita)

O trabalho é uma das formas de dar certo na vida. Mas também está implicado nos trajetos o que Urry definiu como "experiências prazerosas", e

\footnotetext{
${ }^{38}$ Principalmente as que firmam residência em Barcelona. Como Thara Wells e Carla Ferri, que mesmo circulando na Europa inteira permanecem mais tempo nesta cidade da Espanha do que em qualquer outra do mundo, até mais do que no Brasil.
} 
Parker como sendo uma "busca de excitação, liberdade e modernidade" (Parker, 2002, p. 246), presentes no ideal de aprimoramento enquanto travestis no universo da qual fazem parte.

Modernidade exemplificada por Aleika, quando se insere no mercado de concursos de misses no mundo todo. Excitação clara nas falas de Vívian que, além de estar na Espanha trabalhando e tendo reformado a casa dos pais, junta dinheiro para comprar seu automóvel e participa de eventos, sempre que está no Brasil, demonstrando também que busca satisfação pessoal na atividade sexual praticada com os clientes.

As que vão para a Europa na maioria das vezes não estão fazendo sua primeira viagem. Gradualmente elas vão percorrendo caminhos, desde suas cidades - pequenas ou não -, para centros maiores no Brasil, seja a capital do estado onde vivem ou cidades de referência no estado. Daí partem para centros maiores no país, como o Rio de Janeiro e São Paulo, no caso das que têm origem no Nordeste, a maioria de minhas interlocutoras. Poucas partem de sua cidade natal direto para a Europa. Como se vê claramente no mapa organizado por Parker (2002 p. 240), mostrando as rotas de migração interregionais, percorridas também por muitas travestis.

Ser européa é fazer as viagens entre territórios nacionais, pensadas mesmo antes delas terem a certeza de que um dia poderão e conseguirão embarcar com destino à Europa, assim como desembarcar no lugar almejado. Isto implica afirmar que viajar é uma prática criada por um habitus, anterior mesmo à possibilidade real de concretizarem a viagem. Ao mesmo tempo que cria habitus, enquanto "gerado no contexto social", para as travestis. Estes habitus são inicialmente propostos como história incorporada já desde tenra idade, quando passam a viver a travestilidade e conhecem outras travestis, que passam a ser suas referências no mundo em que se inserem. Ou seja, fazem parte de uma agência pedagógica na qual as travestis estão envolvidas assim que decidem modificar-se corporalmente e se inserir no universo da travestilidade.

Ser européa é adquirir uma nova identidade pelo fato de estar circulando entre países e, como afirmou Grazita, não é preciso ir muitas vezes à Europa para ganhar tal identificação. Mas para ganhar status, sim. E principalmente 
para reproduzir habitus, disposição já marcada nelas pelo fato da circulação estar imbricada em sua identidade anterior, mesmo sem se perceberem, como figuras que tem na mobilidade (corporal, de gênero e espacial) sua característica mais importante. O que demonstra uma circulação na formação identitária delas quando iniciam suas buscas de reconhecimento e, para isso, entram em um universo marcado por determinadas estruturas já moldadas, na qual elas pouco podem mexer.

O habitus enquanto "sistema de classificação" (Bourdieu, 1994) diz muito sobre elas, quando se apresentam em shows, quando falam e colocam em suas falas termos que não são da língua portuguesa. O que contribui para que elas se classifiquem como travestis e reproduzam um esquema prático de como ser travesti no Brasil e no mundo, além de, com estas estruturas, estabelecerem novos modelos de comportamento para thes dar maior destaque na sociedade em que vivem: família, amigos e mercado de trabalho.

Pois o contexto no qual elas estão inseridas ampliou-se muito, abrindo para o transnacional, o que adquire relevância na hora de se diferenciar das travestis que não saem do país, principalmente por não poderem provar que estão idôneas perante a justiça, o que lhes impede até de tirar documentos para realizar simples viagens como turistas.

Ellen afirma que, por não sermos acostumadas com a cultura do outro, sofremos com o choque cultural; seu foco de análise é a educação das pessoas:

$\mathrm{Na}$ Europa eu vivia isso, eu tava conversando com as pessoas européias e de repente eu parava de falar, elas começavam a falar, quando eu ia falar eles faziam. "Enquanto você falou eu fiquei calado então espere eu terminar de falar pra você começar a falar!" Então eu entrei em choque de educação. As crianças são assim. A gente brasileiro tem a mania de interromper um ao outro falando, você vê que eu tô numa entrevista aqui, sempre eu paro, se fosse um europeu ele parava e esperava ver o que estava acontecendo, saía pra depois vim conversar comigo e aí toda uma educação. (Ellen)

Este depoimento mostra o quanto de aprendizado pode ser conseguido na viagem a um outro território nacional. O que de melhor ela absorve em 
sua fala e guarda como experiência enquanto européa, o que a diferencia das que não conhecem a Europa, mas também das que não conseguem se apropriar de uma influência enriquecedora em termos culturais, como ela distingue.

Este aprendizado ela trouxe para o Brasil como complemento de sua educação enquanto européa. Ellen, com isso, se dintingue das demais travestis, por perceber a diferenciação e por posicionar-se em relação a ela. Elas conseguem este nome identitário por circularem e por isso permanecerem móveis. Mas é a internalização das representações o que mais se destaca na construção do habitus das travestis brasileiras européas, tal como fica claro na conversa que tive com Roberta, que não se considera européa por ter sido impedida de entrar na Suíça, ressaltando, assim, o lado negativo do lugar e do que se traz de lá, como justificativa pelo fato de não ter dado certo sua tentativa.

Pois, o habitus, enquanto "tendência para conformar e orientar a ação" (Bourdieu, 1994, p. 15), pode ser pensado aquí como aparecendo antes mesmo das viagens das trans à Europa, mas também posterior, porque criado através da experiência concreta das que foram, em conformidade com a orientação destas para levar mais colegas àquele continente. Porque, segundo Bourdieu, determina e é determinado pelas viagens à Europa, o que se configura em praxis social.

Assim, ser européia implica na identificação da travesti também como brasileira, pois as características que elas assumem quando estão por lá muito valem na configuração de seu novo status, sua nova identidade. O que conforma também um novo corpo, o corpo modificado pelo não uso de hormônios "adequados", o que elas tanto reclamam, e um corpo que experimenta mais ainda a ambigüidade, tanto pelo mercado do sexo que pede travestis femininas mais ativas que passivas sexualmente, quanto pelo não controle dos hormônios masculinos, que não são inibidos por falta dos estrogênios conjugados em constante uso, como fazem no Brasil. E, como afirma Bourdieu,

está dentro do mundo social, mas o mundo social está dentro do corpo. E a incorporação do social que a aprendizagem 
realiza é o fundamento da presença no mundo social que a ação socialmente bem sucedida e a experiência ordinária desse mundo supõem necessárias. (Boudieu, 1994, p. 40-41)

Para concluir, gostaria de afirmar que ser européa é desenvolver idéias e comportamentos de "gosto" na apresentação de si, identificação adquirida através de quem se nomeia e é nomeada enquanto européa, e como sê-lo enquanto travestis brasileiras. Comportamento este que distingue e gera conflito entre as diversas categorias de travestis, principalmente quando se trata de condição sócioeconômica que possibilita estar em dia com as novidades da moda e da tecnologia que se implanta no corpo e na linguagem. Ser européa é conseguir status diferenciado ao que se tinha antes de sair do Brasil. E, assim sendo, permanecer circulando entre países, reforçando lá o estereótipo de brasileira, embora com um diferencial do erotismo no corpo, seja este de virilidade ou de feminilidade, e trazer para cá o que de melhor acessaram no primeiro mundo, mesmo que apenas em fotografias.

\section{REFERÊNCIAS BIBLIOGRÁFICAS:}

BOURDIEU, Pierre. Sociologia. São Paulo: Ática, 1994.

BUTLER, Judith. Lenguaje, Poder y Identidad. Ed. Sintesis. Madrid. 1997.

CAMPOS, Maria Consuelo Cunha. Roberta Close e M. Butterfly: Transgênero, Testemunho e Ficção. Revista de Estudos Feministas. Rio de Janeiro, n. 1, p. 37-52, 1999.

CARVALHO, José Murilo de. Cidadania no Brasil: O Longo Caminho. Rio de Janeiro: Civilização Brasileira, 2002.

DEL PRIORI, Mary. Mulheres no Brasil Colonial. São Paulo: Contexto, 2000. 
FREYRE, Gilberto. Casa Grande E Senzala: Formação da Familia Brasileira sob o Regime da Economia Patriarcal. (35 edição) Rio de Janeiro: Record, 1999.

GRABURN, Nelson. Tourism. The Sacred journey (1975). In: COLE, Johneta B. Anthropology for The Nineties. Introductory Readings. Revised and updated, 1988.

Entrevista concedida a Rodrigo Grünewald. Revista Horizontes Antropológicos, Porto Alegre, a. 14, n. 29, p. 341 -368, Jan./Jun. 2008.

HONNETH, Axel. Luta Por Reconhecimento: A Gramática Moral dos Conflitos Sociais. São Paulo: Ed 34, 2003.

MEJÍA, Norma. Transgenerismos. Una Experiencia Transexual Desde la Perspectiva Antropológica. Barcelona: Edicions Bellaterra, 2006.

MESSEDER, Suely. "Lá você vai ser um pedaço de carne..." Entrelaçando o ato performativo da masculinidade subalterna com o mercado sexual dos homens pretos na Galícia. V Encontro Nacional de Migrações. Campinas, Unicamp, 2007.

MORAIS, Grasiela Florêncio de. Ser mulher, pobre e mestiça. Repressão policial e resistência feminina nos logradouros públicos do Recife oitocentista (1836-1842). I Encontro Regional em História Social e Cultural. Recife, UFRPE, 2007.

PARKER, Richard. Abaixo do Equador - Cultura do Desejo, homossexualidade masculina e comunidade gay no Brasil. Rio de Janeiro: Record, 2002.

PELÚCIO SILVA, Larissa. Nos nervos, na carne, na pele. Uma etnografia sobre prostituição travesti e o modelo preventivo de Aids. Tese de Doutorado apresentada ao Programa de Pós Graduaçapo em Ciências Sociais da universidade Federal de São Carlos, mimeo, Junho de 2007.

PINHEIRO, João Amorim. Equipamentos de Lazer GLBTS: Um mercado para empreendedores. Monografia de Especialização. Programa de Pós 
Graduação em Gestão Empreendedora do Turismo. Faculdade Integrada do Recife - FIR, 2005.

PISCITELLI, Adriana. "entre a praia de Iracema e a União européia: turismo sexual internacional e migração feminina”. In: PISCITELLI, Adriana, GREGORI, Maria filomena, CARRARA, Sérgio. (Org.) Sexualidades e Saberes: Convenções e Fronteiras. Ed. Garamond. RJ: 2004.

.Viagens e sexo on line. A internet na geografia do turismo sexual. In: Revista Cadernos Pagu. Revista semestral do Núcleo de Estudos de Gênero - Pagu. Universidade Estadual de Campinas. São Paulo: (25) Julho-dezembro de 2005. p. 281 a 326.

SCOTT, Russel Parry. A família espanhola e a receptividade a migrantes brasileiros. NEPO. Campinas, Out. 2007.

. Turismo, poder y comunidades locales: Fluxos, organização e significados entre Brasil, Europa e os Estados Unidos. Salamanca, 2006

. Antropologias Nacionais: Observando Brasile os Estados Unidos para pensar a Espanha. In: ESPINA BARRIO, Angel-B. Poder, Politica y Cultura. Antropología em Castilla y León e Iberoamérica VII. Recife: Fundação Joaquim Nabuco/Ed. Massangana, 2005.

SILVA, Hélio. Travesti: A invenção do feminino. Etnografia. Rio deJaneiro: Relume/Dumará/ISER, 1993.

- Certas Cariocas. - Arenas do Rio: Travestis evida de rua no Rio de Janeiro. Rio de Janeiro: Relume/Dumará, Prefeitura, 1996.

. Travestis. Entre o espelho e a rua. Rio de Janeiro: Rocco, 2007a.

SILVA, Sandro José da. Carnaval sem rouge nem batom? A repressão aos travestis de "verdade" nos carnavais do Recife entre os anos de 1970 a 1980. Trabalho apresentado e publicado nos Anais eletrônicos do I Encontro Regional em História Social e Cultural. Recife: UFRPE/ DLCH/GEHISC, 2007. UFRPE, Recife. Outubro, 2007b. (mimeo) 
. Entre plumas, interdições e reivindicações: discursos e imagens sobre a homossexualidade masculina na cidade do Recife na década de 1970. Monografia apresentada no Departamento de História da Universidade Federal Rural de Pernambuco. Recife, 2008.

URRY, John. O Olhar do Turista. Lazer e viagens nas Sociedades contemporâneas. São Paulo: Studio Nobel/SESC, 1999. 